\title{
Recanalization Therapy for Acute Ischemic Stroke with Large Vessel Occlusion: Where We Are and What Comes Next?
}

\author{
Mohammad Shafie ${ }^{1}$ (D) $\cdot$ Wengui Yu ${ }^{1}$
}

Received: 11 August 2020 / Revised: 15 November 2020 / Accepted: 18 November 2020 / Published online: 6 January 2021

(C) The Author(s) 2021

\begin{abstract}
In the past 5 years, the success of multiple randomized controlled trials of recanalization therapy with endovascular thrombectomy has transformed the treatment of acute ischemic stroke with large vessel occlusion. The evidence from these trials has now established endovascular thrombectomy as standard of care. This review will discuss the chronological evolution of large vessel occlusion treatment from early medical therapy with tissue plasminogen activator to the latest mechanical thrombectomy. Additionally, it will highlight the potential areas in endovascular thrombectomy for acute ischemic stroke open to exploration and further progress in the next decade.
\end{abstract}

Keywords Acute ischemic stroke (AIS) · Endovascular thrombectomy (EVT) · Ischemic penumbra · Perfusion mismatch · Symptomatic intracerebral hemorrhage $(\mathrm{sICH}) \cdot$ Therapeutic time window $\cdot$ Clinical imaging mismatch

\section{Introduction}

Acute ischemic stroke (AIS) persists as one of the leading causes of long-term disability and mortality both in the United States and globally despite significant advances in stroke care in the past three decades [1]. Large vessel occlusion (LVO) is determined as the underlying etiology in approximately $30-40 \%$ of ischemic strokes $[2,3]$, contributing to $60 \%$ of post-stroke dependence and death at 90 days and $90 \%$ of post-stroke mortality at 6 months [4]. The first line standard of care for patients with AIS within $4.5 \mathrm{~h}$ of symptom onset remains intravenous thrombolysis $[5,6]$. However, this first line treatment has low utilization rate owing to its narrow therapeutic time window and low recanalization rate for LVO [7].

From 2015 to 2016, publication of six successful randomized clinical trials of endovascular thrombectomy (EVT) for patients with large vessel occlusion in the anterior circulation revolutionized ischemic stroke care [8-13]. In the ensuing 3 years, two additional trials showed the benefit of EVT up to $24 \mathrm{~h}$ from last seen well in selected patients with LVO and shifted the treatment paradigm from purely time-based to tissue-based therapy [14,

Mohammad Shafie

shafiem@hs.uci.edu

1 Department of Neurology, University of California, Irvine, $200 \mathrm{~S}$. Manchester Ave., Suite 206, CA 92868 Orange, USA
15]. Despite their resounding success, up to $60 \%$ of subjects in the treatment arms of all the recent EVT trials did not achieve functional independence [8-15]. Therefore, there remains a vast prospect for further advancements in AIS treatments, in particular with EVT, to expand the substantial clinical benefit to a larger patient population. To this end, this review encompasses a comprehensive chronological assessment of the trials and tribulations which led to the development of the evidence supporting the current practice of EVT for AIS treatment and identifies the potential areas for further improvement and deployment of this proven therapy to all whom may benefit.

\section{Evolution of Endovascular Reperfusion Therapies}

\section{From Systemic Intravenous to Local Intra-arterial Thrombolysis}

The narrow therapeutic time window and low recanalization rate of systemic thrombolysis with intravenous (IV) recombinant tissue plasminogen activator (r-tPA) in LVOs led the impetus for the development of endovascular reperfusion therapies [7]. To this end, the (PROACT-II) study remains as the only positive trial to demonstrate the clinical efficacy of local intra-arterial (IA) thrombolysis with recombinant pro-urokinase (r-proUK) in patients with AIS patients of less than 6-h duration caused by a 
proximal middle cerebral artery (MCA) M1 segment occlusion [16]. The PROACT-II trial prohibited any mechanical manipulation of the clot and showed that $40 \%$ of r-proUK and $25 \%$ of control patients had an improved neurologic outcome as measured by a modified Rankin score (mRS) $\leq 2$ at 90 days after stroke onset ( $\mathrm{OR}=2.13 ; 95 \% \mathrm{CI}, 1.02-4.42 ; p=0.04)$ [16]. Despite the encouraging results of PROACT-II, the US FDA did not approve IA treatment of AIS with r-proUK based on the small sample size, marginal significance $(p=0.043)$, and approval for IV tPA treatment. In the era of recent EVT trials, the role of IA thrombolysis remains uncertain. Observational studies of IA r-tPA as either adjuvant or rescue therapy after failed thrombectomy have shown encouraging results with acceptable safety profile and improved reperfusion rates [17, 18]. The American Heart Association/American Stroke Association (AHA/ASA) guidelines continue to recommend IA thrombolysis in appropriately selected AIS patients within $6 \mathrm{~h}$ provided they were not candidates for IV r-tPA (Class I, Level of Evidence: B) [5].

\section{Mechanical Thrombectomy}

Coil retrievers, the first class of mechanical thrombectomy (MT) devices approved by the US FDA, were designed as helical nitinol (a flexible nickel titanium alloy) coils, similar to a corkscrew, to entrap the thrombus and extrude it via the guide catheter [19].

Coil retrievers were approved based on the MERCI and Multi-MERCI trials [20, 21]. The Multi-MERCI trial is more relevant to current practice, as it tested a later generation of coil retriever devices subsequently used in EVT trials and enrolled both patients who were ineligible for and who failed IV r-tPA [21]. The Multi-MERCI trial, a single-arm, multicenter study that enrolled 177 patients, demonstrated partial or complete recanalization in 55\% of patients with the coil retrievers alone and 69\% with rescue use of additional endovascular therapies. This recanalization rate substantially exceeded the historical comparator (the heparin arm of the PROACT 2 trial, with an 18\% partial recanalization rate), indicating technical efficacy. Successful recanalization was associated with higher 90-day independent neurologic outcome of $\mathrm{mRS} \leq 2(49 \%$ vs $10 \%, p<0.001)$ and with a lower mortality rate $(25 \%$ vs $52 \%, p<0.001)[21]$.

\section{Suction Thrombectomy}

Concurrent to the development of coil retrievers, aspiration devices utilizing vacuum aspiration to remove a target occlusive thrombus in AIS were being developed [19]. While manual aspiration of target thrombi can be performed through any microcatheter, progress in developing suction thrombectomy devices required a technical solution to the problem of clogging of aspiration tips. This obstacle was overcome by adding an in-bore separator wire with a bulbous tip inside the bore which the operator could continually advance and retract, disrupting the attached thrombus and pulling it ahead of the catheter [19].

The Penumbra suction thrombectomy system (Penumbra Inc. US) was cleared based on results from a prospective single-arm multicenter trial that tested the safety and efficacy of the device in 125 patients [22]. Partial or better recanalization was reported in $82 \%$ and complete recanalization in $23 \%$ of patients, the latter value equivalent to that attained with coil retrievers in MERCI and Multi-MERCI. Independent neurologic outcome tended to be more frequent with successful compared with unsuccessful recanalization $(29 \%$ vs $9 \%, p=0.06)$ [22]. The aspiration thrombectomy trial, THERAPY, comparing aspiration thrombectomy plus IV tPA with IV r-tPA alone, however, was stopped early (108 of a planned 692 patients) because of external evidence of the added benefit of EVT to IV r-tPA [23]. The primary efficacy outcome of functional independence (90-day $\mathrm{mRS} \leq 2)$ did not differ (38\% vs 30\%; OR:1.4; 95\% CI, 0.6 $3.3 ; p=0.52$ ). The small numbers make these results difficult to interpret, but there was no suggestion of harm [23].

\section{Randomized Controlled Trials of First-Generation Mechanical Thrombectomy Devices}

The clinical utility of endovascular approaches with IA thrombolysis and then first-generation MT devices was tested in three randomized clinical trials including the IMS III [24], MR RESCUE [25], and SYNTHESIS Expansion [26]. The IMS III trial was designed to determine whether combined approach of EVT after the administration of IV r-tPA for patients with moderate-to-severe acute ischemic stroke was more effective than IV r-tPA alone [24]. The SYNTHESIS Expansion trial was designed to investigate whether endovascular treatment, including the options of a mechanical device and IA r-tPA, was more effective than IV r-tPA alone [26]. The MR RESCUE trial tested the hypothesis that a favorable penumbral pattern on imaging could identify AIS patients more likely to benefit from EVT (with Merci Retriever and/or Penumbra System) than standard medical treatment [25]. Unfortunately, all 3 trials failed to show significant clinical benefit of EVT over standard medical therapy. No mandatory requirement for vascular imaging to screen for LVO [24, 25], nascent devices [24-26], and slow enrollment [25] may be the major limitations of these studies [27]. However, a post hoc analysis of data from IMS III showed a significant outcome benefit of EVT in the subgroup of patients with proven LVO [28].

\section{Development of the Second-Generation Mechanical Thrombectomy Devices}

Stent retrievers were originally designed for the purpose of stentassisted coiling and for retracting errant coils dislodged during cerebral endovascular procedures [29]. However, in continued pursuit of higher recanalization rates, a few centers resorted to 
these devices to extract naturally occurring thrombi with unexpected success which ultimately led to the development of the stent retrievers in ischemic stroke endovascular reperfusion therapy [30-32]. The stent retriever technology is based on selfexpanding stents with multiple crisscrossing struts to ensure capture of the thrombus within the stent wall. These devices are fully deployed across the thrombus with the help of a microcatheter and subsequently after capture of the thrombus through the stent struts; the then-unfolded stent plus the thrombus are retrieved, allowing for restoration of flow in the vessel.

The evidence for better reperfusion and good neurological outcomes with stent retrievers compared with the firstgeneration Merci Retrieval System primarily stems from the SWIFT and TREVO 2 phase 2 trials [33, 34]. In the SWIFT trial, a parallel-group, non-inferiority trial, 113 eligible AIS patients were randomized to undergo EVT either by the Solitaire stent retriever $(n=58)$ or the Merci coil retriever $(n=55)$ device. The primary efficacy outcome of successful recanalization without symptomatic intracerebral hemorrhage $(\mathrm{sICH})$ was more likely to be achieved in the Solitaire than the Merci group (64\% vs $24 \% ; p=0.0001$ ). Furthermore, at 90 days, the Solitaire group was more likely to achieve a good neurological outcome (mRS $\leq 2)(58 \%$ vs $33 \% ; p=0.02)$ and a lower mortality rate $(17 \%$ vs $38 \% ; p=0.02)$ than the Merci group [33].

Similarly, in the TREVO 2 trial, 178 eligible AIS patients were randomized to undergo EVT with either the Trevo Pro stent retriever system (Stryker Neurovascular, Kalamazoo, MI) $(n=88)$ or the Merci coil retriever $(n=90)$. The primary outcome of successful recanalization was more likely to be achieved in the Trevo Pro than the Merci group (86\% vs $60 \% ; p<0.0001)$. The Trevo Pro group was also more likely to achieve a good 90-day neurologic outcome $(\mathrm{mRS} \leq 2 ; p=$ $0.013)$ without a difference in 90-day mortality rates $(p=$ 0.1845) than the Merci group [34].

\section{Phase 3 Trials of the Second-Generation Mechanical Thrombectomy Devices}

Lessons from the failed IMS III, SYNTHESIS Expansion, and MR RESCUE trials, as well as the success of SWIFT and TREVO 2 trials, led to the design of several studies with more stringent selection criteria utilizing the next-generation stent retriever thrombectomy devices [24-26, 33, 34]. Subsequently in 2015 and 2016, six randomized controlled trials indisputably established the benefits of using EVT on the clinical outcome of AIS patients compared with those receiving only standard medical care [8-13]. The trials MR CLEAN, EXTEND-IA, and SWIFT PRIME proved the benefit of EVT within the first $6 \mathrm{~h}$ of symptom onset in patients with anterior circulation stroke $[8,9$, 12]. The THRACE trial added further evidence for thrombectomy up to $5 \mathrm{~h}$ from symptom onset [13]. Finally, the ESCAPE and REVASCAT trials proved the benefit of EVT up to $8 \mathrm{~h}$ from symptom onset in anterior circulation stroke $[10,11]$. The main features, key inclusion/exclusion criteria, main imaging modalities, and the thrombectomy devices used in the landmark studies are summarized in Table 1. All trials enrolled patients with severe neurologic deficits and good pre-stroke functional status and patients in both arms received IV r-tPA as a bridge to EVT when eligible. In a meta-analysis of pooled individual patient data from MR CLEAN, ESCAPE, REVASCAT, SWIFT PRIME, and EXTEND-IA, the number needed to treat with EVT to reduced disability by at least one level on the mRS for one patient was 2.6 [35]. This benefit was confirmed across multiple subgroups (including patients older than 80 years and those with very severe strokes as indicated by a baseline NIHSS score greater than 20 [35]. Furthermore, the HERMES meta-analysis corroborated that the odds of better outcomes at 90 days with EVT declined with longer time from symptom onset to arterial puncture with each 1$\mathrm{h}$ delay to reperfusion associated with a less favorable degree of disability (OR, 0.84 [95\% CI, 0.76 to 0.93 ]; ARD, $-6.7 \%$ ) and less functional independence (OR, 0.81 [95\% CI, 0.71 to 0.92], $\mathrm{ARD},-5.2 \%$ [95\% CI, $-8.3 \%$ to $-2.1 \%]$ ) with benefit becoming non-significant after $7.3 \mathrm{~h}$ [36]. Based on the results of these successful clinical trials, EVT for AIS patients presenting within $6 \mathrm{~h}$ of symptom onset from LVO was recommended by the AHA/ASA as standard of care [5].

In modern clinical practice, combined techniques in which a direct aspiration first pass technique (ADAPT) is followed by a stent retrieval to remove any residual thrombus are commonly utilized especially for patients with long-segment occlusions and for intracranial ICA occlusions [37]. The most common technique is Solumbra, which derives its name from the simultaneous use of the Solitaire stent retriever and the Penumbra aspiration system. The technique has many variations using different stent retrieval devices as well as different guide catheters with or without a balloon guide catheter [37].

\section{Neuroimaging in Patient Selection for Endovascular Thrombectomy}

There were great variabilities in the use of imaging tools for patient selection in the recent RCTs as shown in Table 1. In all trials, major early ischemic changes on baseline non-contrast CT (NCCT) were a reason for exclusion. NCCT and CTA were used to select patients with severe deficit and low infarct volume from LVO in most of the clinical trials [8, 9, 11-13]. Advanced imaging tools, including CT perfusion (CTP), diffusion/perfusion MRI, and MRA, were used to identify patients with perfusion mismatch (i.e., small infarct and large ischemic penumbra) in the EXTEND-IA and SWIFT PRIME trials [9, 12]. In the ESCAPE trial, multiphase CTA was used to evaluate the extent of collateral circulation, and patients with no or minimal collaterals were excluded from the study [10]. 
Table 1 Characteristics of the endovascular thrombectomy trials for anterior circulation acute ischemic stroke with large vessel occlusion

\begin{tabular}{|c|c|c|c|c|c|c|c|}
\hline Study & $\begin{array}{l}\text { Patient } \\
(n)\end{array}$ & Key inclusion criteria & Key exclusion criteria & $\begin{array}{l}\text { NIHSS, } \\
\text { median }\end{array}$ & $\begin{array}{l}\text { Main imaging } \\
\text { modalities }\end{array}$ & $\begin{array}{l}\text { Received } \\
\text { IV tPA, } \\
\%\end{array}$ & EVT devices \\
\hline MR CLEAN [8] & 233 & $\begin{array}{c}\text { Age } \geq 18, \text { NIHSS } \geq 2, \text { LVO, } \\
\text { IVT }<4.5 \mathrm{~h}, \text { EVT }<6 \mathrm{~h}\end{array}$ & $\begin{array}{l}\mathrm{BP}>185 / 110 \mathrm{mmHg}, \\
\quad \text { coagulopathy, active } \\
\text { or recent hemorrhage }\end{array}$ & 17 & $\begin{array}{l}\text { CT, CTA, CT } \\
\text { perfusion }(68 \%)\end{array}$ & 87 & $\begin{array}{l}\text { Retrievable } \\
\text { stent }\end{array}$ \\
\hline EXTEND-IA [9] & 35 & $\begin{array}{l}\text { Age } \geq 18, \text { NIHSS } \geq 6, \text { LVO, } \\
\text { IVT }<4.5 \mathrm{~h}, \text { ischemic } \\
\text { core }<70 \mathrm{~mL}, \text { mismatch } \\
\text { volume } \geq 10 \mathrm{~mL} \mathrm{EVT}<6 \mathrm{~h}\end{array}$ & $\begin{array}{l}\text { Intracranial } \\
\text { hemorrhage, any } \\
\text { terminal illness }\end{array}$ & 17 & $\begin{array}{l}\text { CT, CTA, CT } \\
\text { perfusion }\end{array}$ & 100 & Solitaire device \\
\hline ESCAPE [10] & 165 & $\begin{array}{l}\text { Age } \geq 18, \text { NIHSS } \geq 5, \text { LVO } \\
\text { IVT }<4.5 \mathrm{~h}, \text { small infarct } \\
\text { core, EVT }<12 \mathrm{~h}\end{array}$ & $\begin{array}{l}\text { ASPECTS } 0-5 \text {, no or } \\
\text { minimal collaterals }\end{array}$ & 16 & CT, CTA & 73 & $\begin{array}{l}\text { Available } \\
\text { thrombecto- } \\
\text { my device }\end{array}$ \\
\hline SWIFT PRIME [12] & 98 & $\begin{array}{l}\text { Age } 18-80, \text { NIHSS } 8-29, \\
\text { LVO, IVT }<4.5 \mathrm{~h} \text {, small to } \\
\text { moderate infarct core, } \\
\text { EVT }<6 \mathrm{~h}\end{array}$ & $\begin{array}{l}\text { Hemorrhage, tumor, or } \\
\text { vasculitis on CT or } \\
\text { MRI, }>1 / 3 \mathrm{MCA} \\
\text { territory or } 100 \mathrm{~mL} \\
\text { infarct, } \\
\text { DWI-ASPECTS } \leq 5\end{array}$ & 17 & $\begin{array}{l}\text { CT, CTA, CT } \\
\text { perfusion }\end{array}$ & 100 & $\begin{array}{l}\text { Solitaire stent } \\
\text { retriever }\end{array}$ \\
\hline REVASCAT [11] & 103 & $\begin{array}{l}\text { Age } 18-80, \text { NIHSS } \geq 6, \text { LVO, } \\
\text { IVT }<4.5 \mathrm{~h}, \text { EVT }<8 \mathrm{~h}\end{array}$ & $\begin{array}{l}\text { Large ischemic core } \\
\text { (ASPECTS } \leq 7 \text { on } \\
\text { CT or } 6 \text { on DWI } \\
\text { MRI) }\end{array}$ & 17 & CT, CTA, MRI & 68 & $\begin{array}{l}\text { Solitaire stent } \\
\text { retriever }\end{array}$ \\
\hline THRACE [13] & 414 & $\begin{array}{l}\text { Age } 18-80, \text { NIHSS } 10-25 \text {, } \\
\text { LVO, IVT }<4 \text { h, EVT }<5 \text { h }\end{array}$ & $\begin{array}{l}\text { Cervical ICA } \\
\text { stenosis/occlusion }\end{array}$ & 18 & $\begin{array}{l}\text { CT, CTA, or } \\
\text { MRA/MRI }\end{array}$ & 100 & $\begin{array}{l}\text { Stent retriever, } \\
\text { Penumbra }\end{array}$ \\
\hline DAWN [14] & 107 & $\begin{array}{l}\text { Age } \geq 18, \text { NIHSS } \geq 10, \text { LVO, } \\
\text { small infarct core }(<1 / 3 \\
\text { MCA territory), a mismatch } \\
\text { between clinical deficit and } \\
\text { infarct volume } \\
\text { EVT 6-24 h }\end{array}$ & $\begin{array}{l}\text { Rapid improvement in } \\
\text { neuro status, active } \\
\text { or recent } \\
\text { hemorrhage, } \\
\text { coagulopathy }\end{array}$ & 17 & $\begin{array}{l}\text { CT, CTA, MRA, } \\
\text { CT perfusion, } \\
\text { MR } \\
\text { perfusion/- } \\
\text { diffusion }\end{array}$ & 5 & $\begin{array}{l}\text { Trevo stent } \\
\text { retriever }\end{array}$ \\
\hline DEFUSE 3 [15] & 92 & $\begin{array}{l}\text { Age } 18-85, \text { NIHSSS } \geq 6, \mathrm{LVO}, \\
\text { ischemic core }<70 \mathrm{~mL}, \\
\text { mismatch ratio }>1.8, \\
\text { mismatch volume } \geq 15 \mathrm{~mL}, \\
\text { or DWI volume }<25 \mathrm{~mL} \\
\text { EVT } 6-16 \mathrm{~h}\end{array}$ & $\begin{array}{l}\mathrm{BP}>185 / 110 \mathrm{mmHg}, \\
\text { coagulopathy, } \\
\text { ASPECTS score }<6 \\
\text { on non-contrast CT }\end{array}$ & 16 & $\begin{array}{l}\text { CT perfusion } 75 \% \text {, } \\
\text { MR } \\
\text { perfusion/- } \\
\text { diffusion } 25 \%\end{array}$ & 11 & $\begin{array}{l}\text { Any } \\
\text { FDA-appro- } \\
\text { ved stent } \\
\text { retriever }\end{array}$ \\
\hline
\end{tabular}

\section{Early Ischemic Changes on Imaging}

The Alberta Stroke Program Early CT Score (ASPECTS) was originally developed to quantify early ischemic changes on NCCT and is a 10-point scoring system of anatomic regions distributed over the MCA territory on axial NCCT slices [38]. ASPECTS was utilized for patient selection in The ESCAPE, REVASCAT, and SWIFT PRIME trials and demonstrated to serve as a strong predictor of clinical outcome after EVT [11, $12,35]$. The MR CLEAN trial also utilized ASPECTS for patient screening; however, it did not use a threshold for patient exclusion [8]. The HERMES investigators' meta-analysis of the pooled data from the MR CLEAN, ESCAPE, REVASCAT, SWIFT PRIME, and EXTEND-IA trials showed a clear benefit for thrombectomy in patients with ASPECT $\geq 6$ [35]. When the treatment effect was analyzed for the 3 ASPECTS strata of $0-5,6-8$, and 9-10, there was a strong and consistent treatment effect for both ASPECTS 68 and 9-10 group with an adjusted odds ratio of 2.34 (95\% CI: $1.68-3.26)$ and 2.66 (95\% CI: 1.61-4.40), respectively [35]. There was no clear benefit for the 121 patients with ASPECT $0-5$. These findings appear to have validated the use of ASPECTS score 6-10 as surrogate marker of small infarct volume [27].

\section{Imaging Modality to Screen for LVO}

CTA of the head and neck is highly sensitive and specific for detection of LVO [39]. It also provides vasculature images on collaterals, aortic arch, vessel tortuosity, and cerebral ischemia [40-42]. CTA may help the interventionist to plan treatment strategy and reduce procedure time [41].

Reduced contrast enhancement on CTA source images suggests low cerebral blood volume (CBV) [35]. CTA source images appear to be more sensitive in predicting infarct volume and outcome than non-contrast CT [41, 43, 44]. Of note, slow contrast injection and quick image acquisition may cause overestimation of the infarct size. Most recent clinical trials used CTA to screen for LVO in patients with AIS [8-13]. 
Magnetic resonance angiography (MRA) is also a potential option for evaluation of LVO and collateral circulation [45, 46]. Time-of-flight (TOF) and contrast-enhanced (CE) MRA provide good vascular images through the neck and the circle of Willis [45]. CE MRA is performed with IV bolus of gadolinium. It is minimally invasive and offers better diagnostic accuracy than TOF-MRA in detecting LVO [45]. In the SWIFT PRIME, REVASCAT, and THRACE trials, MRA was used in select patients to screen for LVO [11-13].

\section{Assessment of Collateral Circulation}

Collateral circulations are variable among patients [40, 47]. They were shown to predict the size of ischemic penumbra, infarct progression, and functional outcome after LVO [40, 47-49]. CTA, including multiphase or dynamic studies, is a very good imaging modality to assess collaterals $[42,43]$. A major limitation of collateral assessment on CTA is that it is a single snap shot in time of contrast and may misdiagnose adequate collaterals as poor if the image is acquired early in the arterial phase [47, 49]. Digital subtraction angiography (DSA) remains the gold standard for triphasic evaluation of arterial, capillary, and venous circulation with high temporal and spatial resolution [41, 42]. The degree of leptomeningeal collaterals can be semi-quantified by comparing the retrograde pial arterial filling to the contralateral hemisphere [40, 49].

Optimal collateral circulation slows infarct progression and may be a good indication for EVT outside of the traditional time window $[49,50]$. A good leptomeningeal collateral flow is associated with better functional outcome and lower rate of symptomatic intracranial hemorrhages after EVT [47, 48, 51, 52]. A large infarct core and poor collaterals are strong predictors of poor functional outcome [51, 52].

\section{Imaging Modality to Evaluate the Penumbra}

CT perfusion (CTP) is a dynamic contrast-enhanced study developed for the evaluation of the infarct core and ischemic penumbra according to the estimated cerebral blood flow (CBF), mean transition time (MTT), and cerebral blood volume (CBV) [53-56]. The infarct core is defined as an area of brain tissue with $>70 \%$ reduction in $\mathrm{CBF}$ compared to the contralateral hemisphere, and the ischemic penumbra is defined as an area with $>6 \mathrm{~s}$ of delayed contrast arrival [41, 54-57]. The ischemic penumbra is identified by reduced $\mathrm{CBF}$ and normal $\mathrm{CBV}$, whereas the infarct core has a matched decrease in both CBF and CBV [56-59]. The sizes of infarct core and ischemic penumbra are an indirect measurement of collaterals [60]. CTP is not reliable in patients with low cardiac output, cardiac arrhythmias, cervical internal carotid artery stenosis, or a combination of these conditions [61, 62].

CTP was performed only in $66.8 \%$ of the patients in the MR CLEAN trial [8]. Both EXTEND-IA and SWIFT PRIME used CTP to screen patients with small infarct core (IQR 4-32 mL and
0-16 mL, respectively) and large ischemic penumbra for EVT (Table 2) $[9,12]$. Such strict selection criteria led to $60 \%$ and $71 \%$ favorable outcomes, respectively $[9,12]$, the highest ever reported with EVT. However, these studies may have excluded patients who could benefit from EVT [7, 13, 56, 58].

The diffusion/perfusion MRI is also very sensitive in the detection of infarct core and perfusion mismatch [56, 64-67]. MRI may predict clinical response to early reperfusion therapy $[64,65$, 67-69]. However, tissue at risk can be overestimated by perfusion-weighted MRI [70].

Both CTP and MR perfusion can be performed with highspeed CT and MR imaging systems within $10 \min [15,56]$.

\section{Expanding the Therapeutic Time Window}

Recently, the DAWN and DEFUSE 3 clinical trials completely disrupted the time window paradigm in AIS. In the DAWN trial, patients with a LVO AIS within 6 to $24 \mathrm{~h}$ of last known well were randomized to EVT vs standard of care alone [14]. The key inclusion criterion was the presence of a mismatch between the severity of clinical deficits and the volume of the ischemic core on MRI or CTP. The EVT arm and the control group contained $67 \%$ and $47 \%$, respectively, of patients with stroke onset upon awakening. The 90-day rate of functional independence was $49 \%$ after EVT as compared to $13 \%$ in the control group, with patients treated with EVT at a median of $12.5 \mathrm{~h}$ from onset [14].

In the DEFUSE 3 trial, patients with a LVO AIS between 6 and $16 \mathrm{~h}$ after symptom onset were randomized to EVT vs standard of care alone [15]. The major inclusion criterion comprised the radiologic appearance of areas of mismatch between the ischemic core and the ischemic penumbra defined as an initial infarct volume $<70 \mathrm{~mL}$, a ratio of ischemic penumbra to infarct core $\geq 1.8$, and an absolute mismatch $\geq 15 \mathrm{~mL}$. CTP was performed in $73 \%$ of the patients and diffusion/perfusion MRI was done in the other $27 \%$. The EVT arm and the control group contained $49 \%$ and $42 \%$, respectively, of patients with stroke onset upon awakening. The 90-day rate of functional independence was $45 \%$ after EVT as compared to $17 \%$ in the control group as well as an additional $20 \%$ absolute reduction in death or severe disability, with patients treated with EVT at a median of $11 \mathrm{~h}$ from onset [15].

Both DAWN and DEFUSE 3 trials demonstrated significant benefit of EVT within 16-24 h of last known well by selecting patients with clinical imaging mismatch (i.e., severe clinical deficit and small infarct core) per advanced imaging tools. The median NIHSS score with IQR was 17 (13-21) and 16 (10-20) while the median infarct core with IQR was $7.6(2-18)$ and 9.4 (2.3-25.6) $\mathrm{mL}$, respectively (Table 2$)[14,15]$. The astoundingly large treatment effect in these late-window trials, termed the latewindow paradox, has been attributed to both trials having enrolled patients with very slow infarct growth or progression rates [71]. These results led to a paradigm shift from "time window" to 
Table 2 Clinical infarct volume mismatch as eligibility criteria in recent landmark endovascular thrombectomy trials (adapted and modified by permission from $\mathrm{Yu}$ and Jiang [27])

\begin{tabular}{llcccc}
\hline & $\begin{array}{l}\text { Median } \\
\text { NIHSS } \\
\text { IQR) }\end{array}$ & $\begin{array}{l}\text { Median } \\
\text { ASPECTS } \\
\text { (IQR) }\end{array}$ & $\begin{array}{l}\text { Median infarct core per } \\
\text { advanced imaging-mL }^{(\text {IQR })^{a}}\end{array}$ & $\begin{array}{l}\text { sICH }^{b} \\
(\%)\end{array}$ & $\begin{array}{l}\text { Favorable } \\
\text { outcome } \\
(\%)\end{array}$ \\
\hline MR CLEAN [8] & $17(14-21)$ & $9(7-10)$ & - & 7.7 & 33 \\
EXTEND-IA [9] & $17(13-20)$ & NR & $12(4-32)$ & 0 & 71 \\
ESCAPE [10] & $16(13-20)$ & $9(8-10)$ & - & 3.6 & 53 \\
SWIFT PRIME [12] & $17(13-20)$ & $9(8-10)$ & $6(0-16)$ & 1.0 & 60 \\
REVASCAT [11] & $17(14-20)$ & $7(6-9)$ & - & 1.9 & 44 \\
THRAC [13] & $18(15-21)$ & $5-10$ & - & 2 & 53 \\
DAWN [14] & $17(13-21)$ & NR & $7.6(2.0-18.0)$ & 6 & 49 \\
DEFUSE 3 [15] & $16(10-20)$ & $8(7-9)$ & $9.4(2.3-25.6)$ & 7 & 45 \\
\hline
\end{tabular}

$I Q R$ interquartile range, $N R$ not reported

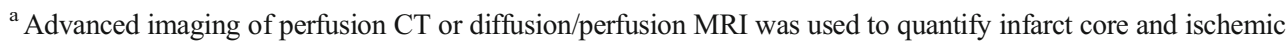
penumbra $[9,12,14,15]$

${ }^{\mathrm{b}} \mathrm{sICH}$ was defined as intraparenchymal hematoma, subarachnoid hemorrhage, or intraventricular hemorrhage associated with a worsening of the NIHSS score by $\geq 4$ points within $24 \mathrm{~h}$ [63] "tissue window" in the treatment of AIS based on utilization of advanced perfusion imaging. Accordingly, in response to these new data, the AHA/ASA guidelines recommend EVT under trial inclusion criteria for LVO AIS up to $24 \mathrm{~h}$ of last known well [5].

\section{Future Directions}

\section{Access to Care}

The advent of highly efficacious EVT for patients with LVO in the era of extended time window has created the need to revise acute stroke system of care. In the United States, typically there have been 3 designation levels of hospital certification in stroke management. These include Comprehensive Stroke Center (CSC), Primary Stroke Centers (PSC), and Acute Stroke Ready Hospital (ASRH), representing the highest to lowest level of stroke readiness. EVT for LVO is primarily offered in CSC [5]. Recently, a new level of care, Thrombectomy-Capable Stroke Centers (TSC), which falls between CSC and PSC has been established in light of the community need for greater access to thrombectomy [72]. However, the proper role of TSCs in the overall stroke system of care remains a controversy as some have raised the concern that inclusion of TSCs in urban areas with CSCs may lead to a lower quality of care by diluting volumes across the system $[73,74]$.

Furthermore, the benefit of patient diversion to different levels of stroke centers, including bypassing the closest PSC to go to a higher level of stroke care (TSC or CSC), remains uncertain [5, 75]. In a large prospective multicenter observational study with almost 1000 AIS patients with anterior circulation LVO, direct admission compared to interhospital transfer to an endovascularcapable stroke center (CSC or TSC) showed a faster median onset-to-revascularization time (202 vs $311.5 \mathrm{~min} ; p<0.001$ ) with a higher proportion achieving functional independence (mRS $\leq 2$ at 90 days) $(60 \%$ vs $52 \%$; OR $=1.38$; $95 \%$ CI, $1.06-$ $1.79 ; p=0.02$ ) and excellent outcome (mRS $0-1$ at 90 days) (47\% vs 38\%; OR $=1.47 ; 95 \%$ CI, $1.13-1.92 ; p=0.005$ ). Based on hypothetical bypass analysis, the authors estimated that limiting the bypass to the nearest endovascular-capable stroke center within 20 miles would result in only a 7-min delay in administration of IV r-tPA but would improve time to EVT by 94 min and accordingly improve outcomes [76]. In rural areas, however, as well as in urban areas with long travel times to CSCs, TSCs could reliably function in the region. Investigations are currently underway to address this challenge with novel modeling and prospective studies [77, 78].

A potential alternative approach proposed to meet the increasing demand for EVT in patients with AIS from LVO focuses on a mobile neuro-interventional team being dispatched to perform the EVT at the PSC rather than transferring the patient to the CSC. Two retrospective reviews based on stroke system of care in New York City and Hokkaido prefecture in Japan have demonstrated shorter door-to-puncture times in this "trip-and-treat" compared to the "drip-and-ship" models [79, 80]. The paradigm has recently been modeled in Germany and was a superior option to drip-and-ship transport with shorter door-to-puncture times $[81,82]$. However, the door-to-puncture times in both "dripand-drive" and "drip-and-ship" models were inferior to those of direct transfers [82].

\section{Patient Selection Criteria}

\section{Large Ischemic Stroke: Beyond Perfusion Imaging}

In the most recent EVT clinical trials, patients with large baseline ischemic core lesion as measured by ASPECTS of $<6$ or ischemic core volume $>70 \mathrm{~mL}$ were largely excluded from 
enrollment per protocol. Advanced perfusion imaging was used in 4 RCTs to define the best treatment effect of EVT $[9,12]$ and extend the treatment window up to $16-24 \mathrm{~h}$ of last known well $[14,15]$. However, the median infarct core was only 12, 6, 7.6, and $9.4 \mathrm{~mL}$ in EXTEND-IA, SWIFT PRIME, DAWN, and DEFUSE 3 trials, $[9,12,14,15]$ respectively, (Table 2) as compared to $49.7 \mathrm{~mL}$ in MR CLEAN [8, 83]. Therefore, the best treatment effect is likely the results of strict selection of patients with small infarct core for EVT [9, 12, 14, 15]. There is growing amount of evidence highlighting the limitations of advanced imaging modalities in the real-world practice.

As suggested by the large treatment effect size observed in DAWN and DEFUSE 3 trials, the selection criteria based on the perfusion imaging thresholds were likely too stringent and could exclude a significant proportion of eligible patients. A number of recent studies have further corroborated this rationale by demonstrating that thrombectomy may benefit DAWN- and/or DEFUSE 3-ineligible patients. In a single-center study of 79 LVO AIS patients, comparison of admission infarct core per CTP and final infarct on follow-up CT showed that CTP overestimated infarct core by more than $10 \mathrm{~mL}$ in $38 \%$ of the patients [84]. In a matched case-controlled study of patients with LVO on CTA and baseline ischemic core greater than $50 \mathrm{~mL}$ on CTP, EVT was associated with significantly improved functional outcome at 90 days [85]. In a study of prospectively collected data, $38 \%$ of the DAWN-ineligible patients and $41 \%$ of DEFUSE 3-ineligible patients achieved functional independency at 90 days after EVT [86]. In another retrospective study, 30\% of DAWN- and/or DEFUSE 3-ineligible patients achieved functional independence after off-label EVT [87]. Two additional studies showed that EVT could benefit patients with large infarct core (DWI-ASPECTS $\leq 5$ or DWI lesion $>70 \mathrm{~mL}$ ) $[88,89]$. These suggestive signals of favorable outcomes for EVT in patients with large baseline core has led to several ongoing clinical trials including the TESLA (Thrombectomy for Emergent Salvage of Large Anterior Circulation Ischemic Stroke) trial (NCT03805308) and TENSION (Efficacy and Safety of Thrombectomy in Stroke With Extended Lesion and Extended Time Window) trial (NCT03094715). The TESLA trial will evaluate the effectiveness of EVT in patients with moderatelarge infarcts (NCCT ASPECTS 2-5) at baseline, while the TENSION trial will investigate the effectiveness of EVT in patients with ASPECTS score of 3-5 and an extended time window (up to $12 \mathrm{~h}$ or unknown time of symptom onset).

Furthermore, the HERMES investigators demonstrated that a 30-min delay in imaging-to-reperfusion time had a similar adverse effect on the functional outcome as a $10-\mathrm{mL}$ increase in ischemic core volume [90]. The HERMES meta-analysis also demonstrated that perfusion mismatch was not associated with either functional independence or functional improvement [35]. The use of perfusion imaging for patient selection has been shown as a potential cause of delay in reperfusion therapy [15], and in a recent cohort study, the use of advanced modality imaging was shown to delay EVT without improvement in clinical outcomes [91]. Therefore, perfusion-based patient selection may deny treatment to patients who might benefit from reperfusion therapy.

While effective clinical trial design in small sample size studies necessitates the use of advanced imaging tools for patient selection in order to achieve the best treatment effect, strict adherence to the perfusion imaging criteria of these RCTs may inadvertently deprive a significant proportion of patients in real-world practice from a proven therapy. Since 5 of the 8 RCTs that independently demonstrated the powerful efficacy of EVT validated the use of ASPECTS score for the assessment of early infarct [8, 10, 11, 13, 15], as shown in Table 2, a simple clinical deficit-CT imaging mismatch (i.e., high NIHSS score and ASPECTS) was proposed as selection criteria to guide EVT for all eligible patients in the fastest puncture-to-reperfusion time in the real-world practice [27].

\section{Thrombectomy Beyond 24 Hours}

The robust treatment effects of DAWN and DEFUSE 3 trials have been explained by the "late-window paradox," postulating that slow progression of the ischemic core with sustained penumbra in AIS patients with LVO contributed to the efficacy of reperfusion therapy despite delayed initiation of treatment [71]. Further analysis of the control arm patients from the DEFUSE 3 trial demonstrated that approximately $20 \%$ of patients with an anterior circulation occlusion presenting within the extended time window and not treated with EVT continued to have a persistent favorable mismatch profile more than $38 \mathrm{~h}$ from their LKW time [92]. Furthermore, EVT was also reported to be safe and effective for patients who met all DAWN trial criteria but were treated beyond $24 \mathrm{~h}$ and up to 6 days of LKW time [93]. Most recently, in a single-centered retrospective review, AIS patients with anterior circulation LVOs treated with EVT beyond $16 \mathrm{~h}$ and up to 10 days of LKW time showed 11-fold higher odds of having an independent functional status at 3 months (mRS: 0-2) [94]. These recent data highlight the need for further clinical trials to determine if patients with a favorable perfusion profile would benefit from reperfusion treatment with EVT beyond $24 \mathrm{~h}$.

\section{"Mild" or "Non-disabling" Stroke}

Since patients with "mild" or "non-disabling" stroke (NIHSS $\leq 5$ ) were excluded from most of the successful EVT trials, the AHA/ASA guidelines do not recommend EVT of LVO in this subgroup [5]. However, recent literature has demonstrated that approximately $30 \%$ of AIS with LVO present with NIHSS $\leq 5$. Consequently, most of these patients may be denied a proven therapy due to low NIHSS scores [95, 96]. Recently, retrospective studies have shown higher odds of improved outcomes for EVT in patients with LVO and NIHSS $\leq 5$ [96-98]. Two multicenter clinical trials, ENDLOW (Endovascular Therapy for 
Low NIHSS Ischemic Strokes) trial (NCT04167527) in North America and MOSTE (Minor Stroke Therapy Evaluation) trial (NCT03796468) in Europe, are investigating the efficacy of EVT in patients with anterior circulation LVO and NIHSS $\leq 5$ or 4 , respectively.

\section{Device and Technology Development to Address Thrombus Characteristics}

The properties of the thrombus are crucial elements in determining its responsiveness to EVT. The exact composition of a thrombus is related to its source and etiology but typically entails of fibrin and red blood cells (RBC) as well as minor white blood cells (WBC) content [99]. Hypodense, fibrin-rich thrombi show reduced recanalization rates regardless of technique [100]. Additionally, a fibrinrich mature thrombus is firmer and less deformable in its interactions with the struts of a stent retriever device [101]. This reduced deformability accordingly increases friction between the thrombus and vessel wall, resulting in each pass at clot retrieval being less effective and potentially higher chance of EVT failure. Newer stent retriever designs that would exert increased radial force to capture the thrombus within their struts may be more effective in the removal of firmer fibrin-rich clots [102].

There are other distinct histological characteristics that may contribute to the understanding if certain thrombi are more resistant than others to extraction via EVT. Most notably, the amount of WBCs in a thrombus has also been associated with the facility of recanalization and duration of the procedure [103]. In more mature thrombi, a lot of WBCs have entered the thrombus, leading to its augmented organization and higher resilience to removal. The thrombus organization is closely related with its stability and its friction with the vessel wall, lending mature thrombi more difficult to extract [104]. Partial endothelialization at the edges of the thrombus [105] and thrombus of atypical origin such as calcified plaques [106], as well as the presence of other plasma constituents such as von Willebrand factor [107], are other features that have been reported as potential contributors associated with the development of mature and firmer thrombi more resistant to removal by EVT. Due to limited understanding of the thrombus histology by stroke neurologists and neurointerventionalists, most patients with AIS from LVO are currently being treated in the same manner. Methods and technologies to determine the composition of the thrombi prior to EVT are a crucial translational research frontier that requires further investigation and undoubtedly will lead to more individualized treatment approaches rather than one size fits all.

\section{Rescue Therapy, Neuroprotection, and Other Adjuvant Treatments}

Despite robust results from the recently successful EVT trials, more than $50 \%$ of patients in the EVT arm did not achieve good functional outcomes. The limitation of the reperfusion therapy stems from their reliance solely on early blood flow restoration without any other protection for the constituents of the neurovascular unit (NVU) in the brain [108, 109].

One of the possibilities for treatment failure is the target vessel re-occlusion. In patients with intracranial atherosclerosis-related LVO, there were reports of longer procedure time and higher rate of re-occlusion [110, 111]. Rescue therapy, including balloon angioplasty, stenting, and intra-arterial glycoprotein IIb/IIIa inhibitor infusion, was empirically used in some of those patients. The rescue therapy was shown to improve functional outcome without an increased risk of sICH. Randomized trials are warrantied to further investigate the safety and benefit of rescue therapy.

Although over 1000 agents targeting neuroprotection failed in clinical trials [108, 112], a few recent studies have demonstrated that some agents may have potential benefits as adjunct to reperfusion therapies. In a post hoc analysis of the URICO-ICTUS trial, administration of uric acid, an endogenous antioxidant, showed higher odds of achieving good functional outcome in subgroup of patients who received tPA and EVT than placebo [113]. In the phase II RHAPSODY trial, 3K3A-APC, a recombinant variant of human activated protein $\mathrm{C}$ (APC), in combination with thrombolysis and EVT, showed a trend towards reduced hemorrhage [114]. In a recent multicenter ESCAPE NA1 trial, Nerinetide, an excitotoxic cell death pathway inhibitor, failed to improve a 90-day functional outcome in patients undergoing EVT plus medical therapy. However, the outcome was improved in patients who did not receive tPA [115]. Hence, neuroprotective agents remain a potential adjuvant therapy and are warrantied for further investigation in AIS intervention.

\section{Conclusions}

The past 5 years has witnessed a revolution in cerebral recanalization therapy for patients with acute LVO. However, there remain many unanswered questions for further investigation, whereby this proven therapy can be expeditiously, safely, and judiciously provided to all eligible patients whom may benefit. Over the next decade, various endeavors will expound on optimization and modifications of stroke systems of care, imaging modality, and clinical criteria to enhance patient selection, as well as technological advancements, rescue, and adjuvant therapies to deliver more efficacious treatment.

Authors' Contributions MS contributed to literature review, preparation of the manuscript draft, and final revision.

WY contributed to the concept, discussions of important intellectual contents, and critical revision.

\section{Compliance with Ethical Standards}

Conflict of Interest MS has nothing to disclose.

WY is a scientific consultant at Amgen, Stryker Neurovascular and Penumbra Inc. 


\section{Appendix of Clinical Trials}

\begin{tabular}{|c|c|}
\hline ENDLOW & Endovascular Therapy for Low NIHSS Ischemic Strokes \\
\hline ESCAPE & $\begin{array}{l}\text { Endovascular Treatment for Small Core and Anterior Circulation Proximal Occlusion With Emphasis on Minimizing CT to } \\
\text { Recanalization Times }\end{array}$ \\
\hline ESCAPE-NA1 & Safety and Efficacy of NA-1 in Subjects Undergoing Endovascular Thrombectomy for Stroke \\
\hline EXTEND-IA & Extending the Time for Thrombolysis in Emergency Neurological Deficits - Intra-Arterial \\
\hline IMS III & Interventional Management of Stroke III \\
\hline MERCI & Mechanical Embolus Removal in Cerebral Ischemia \\
\hline MR CLEAN & Multicenter Randomized Clinical Trial of Endovascular Treatment for Acute Ischemic Stroke in the Netherlands \\
\hline MR RESCUE & Mechanical Retrieval and Recanalization of Stroke Clots Using Embolectomy \\
\hline PROACT-II & Prolyse in Acute Cerebral Thromboembolism II \\
\hline REVASCAT & $\begin{array}{l}\text { Randomized trial of revascularization with Solitaire FR device versus best medical therapy in the treatment of acute stroke due to } \\
\text { anterior circulation large vessel occlusion presenting within } 8 \mathrm{~h} \text { of symptom onset }\end{array}$ \\
\hline RHAPSODY & Safety evaluation of 3K3A-APC in ischemic stroke \\
\hline SWIFT & SOLITAIRE ${ }^{\mathrm{TM}}$ With the Intention for Thrombectomy \\
\hline SWIFT PRIME & Solitaire With the Intention for Thrombectomy as Primary Endovascular Treatment \\
\hline $\begin{array}{l}\text { SYNTEHSIS } \\
\text { Expansion }\end{array}$ & Intra-Arterial Versus Systemic Thrombolysis for Acute Ischemic Stroke \\
\hline TESLA & Thrombectomy for Emergent Salvage of Large Anterior Circulation Ischemic Stroke \\
\hline THERAPY & $\begin{array}{l}\text { The Randomized, Concurrent Controlled Trial to Assess the Penumbra System's Safety and Effectiveness in the Treatment of } \\
\text { Acute Stroke }\end{array}$ \\
\hline THRACE & Trial and Cost Effectiveness of Intra-arterial Thrombectomy in Acute Ischemic Stroke \\
\hline TREVO 2 & Thrombectomy Revascularization of Large Vessel Occlusions in Acute Ischemic Stroke \\
\hline URICO-ICTUS & Safety and efficacy of uric acid in patients with acute stroke \\
\hline
\end{tabular}

Open Access This article is licensed under a Creative Commons Attribution 4.0 International License, which permits use, sharing, adaptation, distribution and reproduction in any medium or format, as long as you give appropriate credit to the original author(s) and the source, provide a link to the Creative Commons licence, and indicate if changes were made. The images or other third party material in this article are included in the article's Creative Commons licence, unless indicated otherwise in a credit line to the material. If material is not included in the article's Creative Commons licence and your intended use is not permitted by statutory regulation or exceeds the permitted use, you will need to obtain permission directly from the copyright holder. To view a copy of this licence, visit http://creativecommons.org/licenses/by/4.0/.

\section{References}

1. Virani SS, Alonso A, Benjamin EJ, Bittencourt MS, Callaway CW, Carson AP, et al. Heart disease and stroke Statistics-2020 update: a report from the American Heart Association. Circulation. 2020;141(9):e139-596. https://doi.org/10.1161/CIR. 0000000000000757.

2. Rennert RC, Wali AR, Steinberg JA, Santiago-Dieppa DR, Olson SE, Pannell JS, et al. Epidemiology, natural history, and clinical presentation of large vessel ischemic stroke. Neurosurgery. 2019;85(suppl_1):S4-8. https://doi.org/10.1093/neuros/nyz042.

3. Waqas M, Rai AT, Vakharia K, Chin F, Siddiqui AH. Effect of definition and methods on estimates of prevalence of large vessel occlusion in acute ischemic stroke: a systematic review and meta- analysis. J Neurointerv Surg. 2020;12(3):260-5. https://doi.org/ 10.1136/neurintsurg-2019-015172.

4. Malhotra K, Gornbein J, Saver JL. Ischemic strokes due to largevessel occlusions contribute disproportionately to stroke-related dependence and death: a review. Front Neurol. 2017;8:651. https://doi.org/10.3389/fneur.2017.00651.

5. Powers WJ, Rabinstein AA, Ackerson T, Adeoye OM, Bambakidis NC, Becker K, et al. Guidelines for the early management of patients with acute ischemic stroke: 2019 update to the 2018 guidelines for the early management of acute ischemic stroke: a guideline for healthcare professionals from the American Heart Association/American Stroke Association. Stroke. 2019;50(12):e344-418. https://doi.org/10.1161/STR. 0000000000000211.

6. Ahmed N, Audebert H, Turc G, Cordonnier C, Christensen H, Sacco S, et al. Consensus statements and recommendations from the ESO-Karolinska Stroke Update Conference, Stockholm 11-13 November 2018. Eur Stroke J. 2019;4(4):307-17. https://doi.org/ $10.1177 / 2396987319863606$.

7. Rha JH, Saver JL. The impact of recanalization on ischemic stroke outcome: a meta-analysis. Stroke. 2007;38(3):967-73. https://doi. org/10.1161/01.STR.0000258112.14918.24.

8. Berkhemer OA, Fransen PS, Beumer D, van den Berg LA, Lingsma HF, Yoo AJ, et al. A randomized trial of intra-arterial treatment for acute ischemic stroke. N Engl J Med. 2015;372(1): 11-20. https://doi.org/10.1056/NEJMoa1411587.

9. Campbell BC, Mitchell PJ, Kleinig TJ, Dewey HM, Churilov L, Yassi N, et al. Endovascular therapy for ischemic stroke with 
perfusion-imaging selection. N Engl J Med. 2015;372(11):1009 18. https://doi.org/10.1056/NEJMoa1414792.

10. Goyal M, Demchuk AM, Menon BK, Eesa M, Rempel JL, Thornton J, et al. Randomized assessment of rapid endovascular treatment of ischemic stroke. N Engl J Med. 2015;372(11):1019 30. https://doi.org/10.1056/NEJMoa1414905.

11. Jovin TG, Chamorro A, Cobo E, de Miquel MA, Molina CA, Rovira A, et al. Thrombectomy within 8 hours after symptom onset in ischemic stroke. N Engl J Med. 2015;372(24):2296306. https://doi.org/10.1056/NEJMoa1503780.

12. Saver JL, Goyal M, Bonafe A, Diener HC, Levy EI, Pereira VM, et al. Stent-retriever thrombectomy after intravenous t-PA vs. t-PA alone in stroke. N Engl J Med. 2015;372(24):2285-95. https://doi. org/10.1056/NEJMoa1415061.

13. Bracard S, Ducrocq X, Mas JL, Soudant M, Oppenheim C, Moulin T, et al. Mechanical thrombectomy after intravenous alteplase versus alteplase alone after stroke (THRACE): a randomised controlled trial. Lancet Neurol. 2016;15(11):1138 47. https://doi.org/10.1016/s1474-4422(16)30177-6.

14. Nogueira RG, Jadhav AP, Haussen DC, Bonafe A, Budzik RF, Bhuva P, et al. Thrombectomy 6 to 24 hours after stroke with a mismatch between deficit and infarct. N Engl J Med. 2018;378(1): 11-21. https://doi.org/10.1056/NEJMoa1706442.

15. Albers GW, Marks MP, Kemp S, Christensen S, Tsai JP, OrtegaGutierrez S, et al. Thrombectomy for stroke at 6 to 16 hours with selection by perfusion imaging. N Engl J Med. 2018;378(8):70818. https://doi.org/10.1056/NEJMoa1713973.

16. Furlan A, Higashida R, Wechsler L, Gent M, Rowley H, Kase C, et al. Intra-arterial prourokinase for acute ischemic stroke - the PROACT II study: a randomized controlled trial. JAMA. 1999;282(21):2003-11.

17. Heiferman DM, Li DD, Pecoraro NC, Smolenski AM, Tsimpas A, Ashley WW Jr. Intra-arterial alteplase thrombolysis during mechanical thrombectomy for acute ischemic stroke. J Stroke Cerebrovasc Dis. 2017;26(12):3004-8. https://doi.org/10.1016/j. jstrokecerebrovasdis.2017.07.031.

18. Zaidi SF, Castonguay AC, Jumaa MA, Malisch TW, Linfante I, Marden FA, et al. Intra-arterial thrombolysis as rescue therapy for large vessel occlusions. Stroke. 2019;50(4):1003-6. https://doi. org/10.1161/STROKEAHA.118.024442.

19. Przybylowski CJ, Ding D, Starke RM, Durst CR, Crowley RW, Liu KC. Evolution of endovascular mechanical thrombectomy for acute ischemic stroke. World J Clin Cases. 2014;2(11):614-22. https://doi.org/10.12998/wjcc.v2.i11.614.

20. Smith WS, Sung G, Starkman S, Saver JL, Kidwell CS, Gobin YP, et al. Safety and efficacy of mechanical embolectomy in acute ischemic stroke: results of the MERCI trial. Stroke. 2005;36(7): 1432-8. https://doi.org/10.1161/01.STR.0000171066.25248.1d.

21. Smith WS, Sung G, Saver J, Budzik R, Duckwiler G, Liebeskind DS, et al. Mechanical thrombectomy for acute ischemic stroke: final results of the multi MERCI trial. Stroke. 2008;39(4):120512. https://doi.org/10.1161/STROKEAHA.107.497115.

22. Penumbra Pivotal Stroke Trial I. The penumbra pivotal stroke trial: safety and effectiveness of a new generation of mechanical devices for clot removal in intracranial large vessel occlusive disease. Stroke. 2009;40(8):2761-8. https://doi.org/10.1161/ STROKEAHA.108.544957.

23. Mocco J, Zaidat OO, von Kummer R, Yoo AJ, Gupta R, Lopes D, et al. Aspiration thrombectomy after intravenous alteplase versus intravenous alteplase alone. Stroke. 2016;47(9):2331-8. https:// doi.org/10.1161/STROKEAHA.116.013372.

24. Broderick JP, Palesch YY, Demchuk AM, Yeatts SD, Khatri P, Hill MD, et al. Endovascular therapy after intravenous t-PA versus t-PA alone for stroke. N Engl J Med. 2013;368(10):893-903. https://doi.org/10.1056/NEJMoa1214300.
25. Kidwell CS, Jahan R, Gornbein J, Alger JR, Nenov V, Ajani Z, et al. A trial of imaging selection and endovascular treatment for ischemic stroke. N Engl J Med. 2013;368(10):914-23. https://doi. org/10.1056/NEJMoa1212793.

26. Ciccone A, Valvassori L, Nichelatti M, Sgoifo A, Ponzio M, Sterzi R, et al. Endovascular treatment for acute ischemic stroke. N Engl J Med. 2013;368(10):904-13. https://doi.org/10.1056/ NEJMoa1213701.

27. Yu W, Jiang WJ. A simple imaging guide for endovascular thrombectomy in acute ischemic stroke: from time window to perfusion mismatch and beyond. Front Neurol. 2019;10:502. https://doi.org/10.3389/fneur.2019.00502.

28. Demchuk AM, Goyal M, Yeatts SD, Carrozzella J, Foster LD, Qazi EM, et al. Recanalization and clinical outcome of occlusion sites at baseline CT angiography in IMS III. Radiology. 2014;273: 202-10.

29. Smith WS, Furlan AJ. Brief history of endovascular acute ischemic stroke treatment. Stroke. 2016;47:e23-e6. https://doi.org/10. 1161/STROKEAHA.115.010863.

30. Brekenfeld C, Schroth G, Mordasini P, Fischer U, Mono ML, Weck A, et al. Impact of retrievable stents on acute ischemic stroke treatment. AJNR Am J Neuroradiol. 2011;32(7):1269-73. https://doi.org/10.3174/ajnr.A2494.

31. Hauck EF, Mocco J, Snyder KV, Levy EI. Temporary endovascular bypass: a novel treatment for acute stroke. AJNR Am J Neuroradiol. 2009;30(8):1532-3. https://doi.org/10.3174/ ajnr.A1536.

32. Kelly ME, Furlan AJ, Fiorella D. Recanalization of an acute middle cerebral artery occlusion using a self-expanding, reconstrainable, intracranial microstent as a temporary endovascular bypass. Stroke. 2008;39(6):1770-3. https://doi.org/ 10.1161/STROKEAHA.107.506212.

33. Saver JL, Jahan R, Levy EI, Jovin TG, Baxter B, Nogueira RG, et al. Solitaire flow restoration device versus the Merci retriever in patients with acute ischaemic stroke (SWIFT): a randomised, parallel-group, non-inferiority trial. Lancet. 2012;380(9849):1241-9. https://doi.org/10.1016/S0140-6736(12)61384-1.

34. Nogueira RG, Lutsep HL, Gupta R, Jovin TG, Albers GW, Walker GA, et al. Trevo versus Merci retrievers for thrombectomy revascularisation of large vessel occlusions in acute ischaemic stroke (TREVO 2): a randomised trial. Lancet. 2012;380(9849): 1231-40. https://doi.org/10.1016/S0140-6736(12)61299-9.

35. Goyal M, Menon BK, van Zwam WH, Dippel DWJ, Mitchell PJ, Demchuk AM, et al. Endovascular thrombectomy after largevessel ischaemic stroke: a meta-analysis of individual patient data from five randomised trials. Lancet. 2016;387(10029):1723-31. https://doi.org/10.1016/s0140-6736(16)00163-x.

36. Saver JL, Goyal M, van der Lugt A, Menon BK, Majoie CB, Dippel DW, et al. Time to treatment with endovascular thrombectomy and outcomes from ischemic stroke: a meta-analysis. JAMA. 2016;316(12):1279-88. https://doi.org/10.1001/jama. 2016.13647.

37. Samaniego EA, Roa JA, Limaye K, Adams HP Jr. Mechanical thrombectomy: emerging technologies and techniques. J Stroke Cerebrovasc Dis. 2018;27(10):2555-71. https://doi.org/10.1016/ j.jstrokecerebrovasdis.2018.05.025.

38. Pexman J, Barber PA, Hill MD, Sevick RJ, Demchuk AM, Hudon ME, et al. Use of the Alberta Stroke Program Early CT Score (ASPECTS) for assessing CT scans in patients with acute stroke. AJNR Am J Neuroradiol. 2001;22:1534-42.

39. Lev MH, Farkas J, Rodriguez VR, Schwamm LH, Hunter GJ, Putman CM, et al. CT angiography in the rapid triage of patients with hyperacute stroke to intra-arterial thrombolysis: accuracy in the detection of large vessel thrombus. J Comput Assist Tomogr. 2001;25(4):520-8. https://doi.org/10.1097/00004728200107000-00003. 
40. Maas MB, Lev MH, Ay H, Singhal AB, Greer DM, Smith WS, et al. Collateral vessels on CT angiography predict outcome in acute ischemic stroke. Stroke. 2009;40(9):3001-5. https://doi. org/10.1161/STROKEAHA.109.552513.

41. Menon BK, Campbell BC, Levi C, Goyal M. Role of imaging in current acute ischemic stroke workflow for endovascular therapy. Stroke. 2015;46(6):1453-61. https://doi.org/10.1161/ STROKEAHA.115.009160.

42. Menon BK, d'Esterre CD, Qazi EM, Almekhlafi M, Hahn L, Demchuk AM, et al. Multiphase CT angiography: a new tool for the imaging triage of patients with acute ischemic stroke. Radiology. 2015;275(2):510-20. https://doi.org/10.1148/radiol. 15142256 .

43. Coutts SB, Lev MH, Eliasziw M, Roccatagliata L, Hill MD, Schwamm LH, et al. ASPECTS on CTA source images versus unenhanced CT: added value in predicting final infarct extent and clinical outcome. Stroke. 2004;35(11):2472-6. https://doi.org/10. 1161/01.STR.0000145330.14928.2a.

44. Pulli B, Schaefer PW, Hakimelahi R, Chaudhry ZA, Lev MH, Hirsch JA, et al. Acute ischemic stroke: infarct core estimation on $\mathrm{CT}$ angiography source images depends on CT angiography protocol. Radiology. 2012;262(2):593-604. https://doi.org/10. 1148/radiol.11110896.

45. Vu D, Gonzalez RG, Schaefer PW. Conventional MRI and MR angiography of stroke. In: Gonzalez RG, Hirsch J, Koroshetz W, et al., editors. Acute Ischemic Stroke: Imaging and Intervention. Berlin: Springer-Verlag; 2006. p. 115-35.

46. Chalela JA, Kidwell CS, Nentwich LM, Luby M, Butman JA, Demchuk AM, et al. Magnetic resonance imaging and computed tomography in emergency assessment of patients with suspected acute stroke: a prospective comparison. Lancet. 2007;369(9558): 293-8. https://doi.org/10.1016/S0140-6736(07)60151-2.

47. Liebeskind DS, Tomsick TA, Foster LD, Yeatts SD, Carrozzella J, Demchuk AM, et al. Collaterals at angiography and outcomes in the Interventional Management of Stroke (IMS) III trial. Stroke. 2014;45(3):759-64. https://doi.org/10.1161/STROKEAHA.113. 004072 .

48. Leng X, Fang H, Leung TW, Mao C, Miao Z, Liu L, et al. Impact of collaterals on the efficacy and safety of endovascular treatment in acute ischaemic stroke: a systematic review and meta-analysis. J Neurol Neurosurg Psychiatry. 2016;87(5):537-44. https://doi.org/ 10.1136/jnnp-2015-310965.

49. Miteff F, Levi CR, Bateman GA, Spratt N, McElduff P, Parsons MW. The independent predictive utility of computed tomography angiographic collateral status in acute ischaemic stroke. Brain. 2009;132(Pt 8):2231-8. https://doi.org/10.1093/brain/awp155.

50. Ribo M, Flores A, Rubiera M, Pagola J, Sargento-Freitas J, Rodriguez-Luna D, et al. Extending the time window for endovascular procedures according to collateral pial circulation. Stroke. 2011;42(12):3465-9. https://doi.org/10.1161/ STROKEAHA.111.623827.

51. Bang OY, Saver JL, Kim SJ, Kim GM, Chung CS, Ovbiagele B, et al. Collateral flow predicts response to endovascular therapy for acute ischemic stroke. Stroke. 2011;42(3):693-9. https://doi.org/ 10.1161/STROKEAHA.110.595256.

52. Bang OY, Saver JL, Kim SJ, Kim GM, Chung CS, Ovbiagele B, et al. Collateral flow averts hemorrhagic transformation after endovascular therapy for acute ischemic stroke. Stroke. 2011;42(8):2235-9. https://doi.org/10.1161/STROKEAHA.110. 604603 .

53. Koenig M, Klotz E, Luka B, Venderink DJ, Spittler JF, Heuser L. Perfusion CT of the brain: diagnostic approach for early detection of ischemic stroke. Radiology. 1998;209(1):85-93. https://doi. org/10.1148/radiology.209.1.9769817.

54. Koenig M, Kraus M, Theek C, Klotz E, Gehlen W, Heuser L. Quantitative assessment of the ischemic brain by means of perfusion-related parameters derived from perfusion CT. Stroke. 2001;32(2):431-7. https://doi.org/10.1161/01.str.32.2.431.

55. Wintermark M, Reichhart M, Thiran JP, Maeder P, Chalaron M, Schnyder P, et al. Prognostic accuracy of cerebral blood flow measurement by perfusion computed tomography, at the time of emergency room admission, in acute stroke patients. Ann Neurol. 2002;51(4):417-32. https://doi.org/10.1002/ana.10136.

56. Schramm P, Schellinger PD, Klotz E, Kallenberg K, Fiebach JB, Kulkens S, et al. Comparison of perfusion computed tomography and computed tomography angiography source images with perfusion-weighted imaging and diffusion-weighted imaging in patients with acute stroke of less than 6 hours' duration. Stroke. 2004;35(7):1652-8. https://doi.org/10.1161/01.STR. 0000131271.54098.22.

57. Murphy BD, Fox AJ, Lee DH, Sahlas DJ, Black SE, Hogan MJ, et al. Identification of penumbra and infarct in acute ischemic stroke using computed tomography perfusion-derived blood flow and blood volume measurements. Stroke. 2006;37(7):1771-7. https://doi.org/10.1161/01.STR.0000227243.96808.53.

58. Bouslama M, Haussen DC, Grossberg JA, Dehkharghani S, Bowen MT, Rebello LC, et al. Computed tomographic perfusion selection and clinical outcomes after endovascular therapy in large vessel occlusion stroke. Stroke. 2017;48(5):1271-7. https://doi. org/10.1161/STROKEAHA.116.015636.

59. Turk A, Magarik JA, Chaudry I, Turner RD, Nicholas J, Holmstedt CA, et al. CT perfusion-guided patient selection for endovascular treatment of acute ischemic stroke is safe and effective. J Neurointerv Surg. 2012;4(4):261-5. https://doi.org/10. 1136/neurintsurg-2011-010067.

60. Bang OY, Goyal M, Liebeskind DS. Collateral circulation in ischemic stroke: assessment tools and therapeutic strategies. Stroke. 2015;46(11):3302-9. https://doi.org/10.1161/STROKEAHA. 115.010508 .

61. Lui YW, Tang ER, Allmendinger AM, Spektor V. Evaluation of CT perfusion in the setting of cerebral ischemia: patterns and pitfalls. AJNR Am J Neuroradiol. 2010;31(9):1552-63. https:// doi.org/10.3174/ajnr.A2026.

62. Bivard A, Levi C, Spratt N, Parsons M. Perfusion CT in Acute Stroke: A comprehensive analysis of infarct and penumbra. Radiology. 2013;267(2):543-50. https://doi.org/10.1148/radiol. 12120971/-/DC1.

63. Lees KR, Bluhmki E, von Kummer R, Brott TG, Toni D, Grotta $\mathrm{JC}$, et al. Time to treatment with intravenous alteplase and outcome in stroke: an updated pooled analysis of ECASS, ATLANTIS, NINDS, and EPITHET trials. Lancet. 2010;375(9727):1695-703. https://doi.org/10.1016/S01406736(10)60491-6.

64. Barber PA, Darby DG, Desmond PM, Yang Q, Gerraty RP, Jolley $\mathrm{D}$, et al. Prediction of stroke outcome with echoplanar perfusionand diffusion-weighted MRI. Neurology. 1998;51(2):418-26. https://doi.org/10.1212/wnl.51.2.418.

65. Rordorf GA, Koroshetz W, Copen WA, Cramer SC, Schaefer PW, Budzik R, et al. Regional ischemia and ischemic injury in patients with acute middle cerebral artery stroke as defined by early diffusion-weighted and perfusion-weighted MRI. Stroke. 1998;29:939-43.

66. Tong DC, Yenari MA, Albers GW, O’Brien M, Marks MP Moseley ME. Correlation of perfusion- and diffusion weighted MRI with NIHSS score in acute $(<6.5$ hour $)$ ischemic stroke. Neurology. 1998;50:864-9.

67. Kidwell C, Saver J, Mattiello J, Starkman S, Vinuela F, Duckwiler $\mathrm{G}$, et al. Thrombolytic reversal of acute human cerebral ischemic injury shown by diffusion:perfusion magnetic resonance imaging. Ann Neurol. 2000;47:462-9.

68. Albers GW, Thijs VN, Wechsler L, Kemp S, Schlaug G, Skalabrin $\mathrm{E}$, et al. Magnetic resonance imaging profiles predict clinical 
response to early reperfusion: the diffusion and perfusion imaging evaluation for understanding stroke evolution (DEFUSE) study. Ann Neurol. 2006;60(5):508-17. https://doi.org/10.1002/ana. 20976.

69. Rohl L, Ostergaard L, Simonsen CZ, Vestergaard-Poulsen P, Andersen G, Sakoh M, et al. Viability thresholds of ischemic penumbra of hyperacute stroke defined by perfusion-weighted MRI and apparent diffusion coefficient. Stroke. 2001;32(5): 1140-6. https://doi.org/10.1161/01.str.32.5.1140.

70. Kucinski T, Naumann D, Knab R, Schoder V, Wegener S, Fiehler $\mathrm{J}$, et al. Tissue at risk is overestimated in perfusion- weighted imaging- MR imaging in acute stroke patients without vessel recanalization. AJNR Am J Neuroradiol. 2005;26:815-9.

71. Albers GW. Late window paradox. Stroke. 2018;49(3):768-71. https://doi.org/10.1161/STROKEAHA.117.020200.

72. Adeoye O, Nystrom KV, Yavagal DR, Luciano J, Nogueira RG, Zorowitz RD, et al. Recommendations for the establishment of stroke systems of care: a 2019 update. Stroke. 2019;50(7):e187210. https://doi.org/10.1161/STR.0000000000000173.

73. Southerland AM, Johnston KC, Molina CA, Selim MH, Kamal N, Goyal M. Suspected large vessel occlusion: should emergency medical services transport to the nearest primary stroke center or bypass to a comprehensive stroke center with endovascular capabilities? Stroke. 2016;47(7):1965-7. https://doi.org/10.1161/ STROKEAHA.115.011149.

74. Mack W, Mocco J, Hirsch J, Chen M, Elijovich L, Tarr R, et al. Thrombectomy stroke centers: the current threat to regionalizing stroke care. J Neurointerv Surg. 2018;10(2):99-101.

75. Benoit JL, Khatri P, Adeoye OM, Broderick JP, McMullan JT, Scheitz JF, et al. Prehospital triage of acute ischemic stroke patients to an intravenous tPA-ready versus endovascular-ready hospital: a decision analysis. Prehosp Emerg Care. 2018;22(6):72233. https://doi.org/10.1080/10903127.2018.1465500.

76. Froehler MT, Saver JL, Zaidat OO, Jahan R, Aziz-Sultan MA, Klucznik RP, et al. Interhospital transfer before thrombectomy is associated with delayed treatment and worse outcome in the STRATIS registry (systematic evaluation of patients treated with neurothrombectomy devices for acute ischemic stroke). Circulation. 2017;136(24):2311-21. https://doi.org/10.1161/ CIRCULATIONAHA.117.028920.

77. Bohmann FO, Kurka N, du Mesnil de Rochemont R, Gruber K, Guenther J, Rostek P, et al. Simulation-Based Training of the Rapid Evaluation and Management of Acute Stroke (STREAM)-a prospective single-arm multicenter trial. Front Neurol. 2019;10:969. https://doi.org/10.3389/fneur.2019.00969.

78. Behrndtz A, Johnsen SP, Valentin JB, Gude MF, Blauenfeldt RA, Andersen G, et al. TRIAGE-STROKE: Treatment strategy In Acute larGE vessel occlusion: prioritize IV or endovascular treatment-a randomized trial. Int J Stroke. 2020;15(1):103-8. https://doi.org/10.1177/1747493019869830.

79. Wei D, Oxley TJ, Nistal DA, Mascitelli JR, Wilson N, Stein L, et al. Mobile interventional stroke teams lead to faster treatment times for thrombectomy in large vessel occlusion. Stroke. 2017;48(12):3295-300. https://doi.org/10.1161/STROKEAHA. 117.018149 .

80. Osanai T, Ito Y, Ushikoshi S, Aoki T, Kawabori M, Fujiwara K, et al. Efficacy of 'drive and retrieve' as a cooperative method for prompt endovascular treatment for acute ischemic stroke. J Neurointerv Surg. 2019;11(8):757-61. https://doi.org/10.1136/ neurintsurg-2018-014296.

81. Brekenfeld C, Goebell E, Schmidt H, Henningsen H, Kraemer C, Tebben J, et al. 'Drip-and-drive': shipping the neurointerventionalist to provide mechanical thrombectomy in primary stroke centers. J Neurointerv Surg. 2018;10(10):932-6. https://doi.org/10.1136/neurintsurg-2017-013634.
82. Seker F, Fiehler J, Mohlenbruch MA, Heimann F, Flottmann F, Ringleb PA, et al. Time metrics to endovascular thrombectomy in 3 triage concepts: a prospective, observational study (NEUROSQUAD). Stroke. 2020;51(1):335-7. https://doi.org/10. 1161/STROKEAHA.119.027050.

83. Geuskens RR, Borst J, Lucas M, Boers AM, Berkhemer OA, Roos YB, et al. Characteristics of misclassified CT perfusion ischemic core in patients with acute ischemic stroke. PLoS One. 2015;10(11):e0141571. https://doi.org/10.1371/journal.pone. 0141571.

84. Boned S, Padroni M, Rubiera M, Tomasello A, Coscojuela P, Romero N, et al. Admission CT perfusion may overestimate initial infarct core: the ghost infarct core concept. J Neurointerv Surg. 2017;9(1):66-9. https://doi.org/10.1136/neurintsurg-2016012494.

85. Rebello LC, Bouslama M, Haussen DC, Dehkharghani S, Grossberg JA, Belagaje S, et al. Endovascular treatment for patients with acute stroke who have a large ischemic core and large mismatch imaging profile. Jama Neurol. 2017;74(1):34-40. https://doi.org/10.1001/jamaneurol.2016.3954.

86. Ducroux C, Khoury N, Lecler A, Blanc R, Chetrit A, Redjem H, et al. Application of the DAWN clinical imaging mismatch and DEFUSE 3 selection criteria: benefit seems similar but restrictive volume cut-offs might omit potential responders. Eur J Neurol. 2018;25(8):1093-9. https://doi.org/10.1111/ene.13660.

87. Desai SM, Rocha M, Molyneaux BJ, Starr M, Kenmuir CL, Gross BA, et al. Thrombectomy 6-24 hours after stroke in trial ineligible patients. J Neurointerv Surg. 2018;10(11):1033-7. https://doi.org/ 10.1136/neurintsurg-2018-013915.

88. Gautheron V, Xie Y, Tisserand M, Raoult H, Soize S, Naggara O, et al. Outcome after reperfusion therapies in patients with large baseline diffusion-weighted imaging stroke lesions: a THRACE trial (mechanical thrombectomy after intravenous alteplase versus alteplase alone after stroke) subgroup analysis. Stroke. 2018;49(3):750-3. https://doi.org/10.1161/STROKEAHA.117. 020244 .

89. Manceau PF, Soize S, Gawlitza M, Fabre G, Bakchine S, Durot C, et al. Is there a benefit of mechanical thrombectomy in patients with large stroke (DWI-ASPECTS $</=5$ )? Eur J Neurol. 2018;25(1):105-10. https://doi.org/10.1111/ene.13460.

90. Campbell BCV, Majoie C, Albers GW, Menon BK, Yassi N, Sharma $\mathrm{G}$, et al. Penumbral imaging and functional outcome in patients with anterior circulation ischaemic stroke treated with endovascular thrombectomy versus medical therapy: a metaanalysis of individual patient-level data. Lancet Neurol. 2019;18(1):46-55. https://doi.org/10.1016/S1474-4422(18) 30314-4.

91. Sheth KN, Terry JB, Nogueira RG, Horev A, Nguyen TN, Fong $\mathrm{AK}$, et al. Advanced modality imaging evaluation in acute ischemic stroke may lead to delayed endovascular reperfusion therapy without improvement in clinical outcomes. J Neurointerv Surg. 2013;5(Suppl 1):i62-5. https://doi.org/10.1136/neurintsurg2012-010512.

92. Christensen S, Mlynash M, Kemp S, Yennu A, Heit JJ, Marks $\mathrm{MP}$, et al. Persistent target mismatch profile $>24$ hours after stroke onset in DEFUSE 3. Stroke. 2019;50(3):754-7. https://doi.org/10. 1161/STROKEAHA.118.023392.

93. Desai SM, Haussen DC, Aghaebrahim A, Al-Bayati AR, Santos R, Nogueira RG, et al. Thrombectomy 24 hours after stroke: beyond DAWN. J Neurointerv Surg. 2018;10(11):1039-42. https:// doi.org/10.1136/neurintsurg-2018-013923.

94. Kim BJ, Menon BK, Kim JY, Shin DW, Baik SH, Jung C, et al. Endovascular treatment after stroke due to large vessel occlusion for patients presenting very late from time last known well. Jama Neurol. 2020. https://doi.org/10.1001/jamaneurol.2020.2804. 
95. Heldner MR, Jung S, Zubler C, Mordasini P, Weck A, Mono ML, et al. Outcome of patients with occlusions of the internal carotid artery or the main stem of the middle cerebral artery with NIHSS score of less than 5: comparison between thrombolysed and nonthrombolysed patients. J Neurol Neurosurg Psychiatry. 2015;86(7):755-60. https://doi.org/10.1136/jnnp-2014-308401.

96. Heldner MR, Chaloulos-Iakovidis P, Panos L, Volbers B, Kaesmacher J, Dobrocky T, et al. Outcome of patients with large vessel occlusion in the anterior circulation and low NIHSS score. J Neurol. 2020;267(6):1651-62. https://doi.org/10.1007/s00415020-09744-0.

97. Nagel S, Bouslama M, Krause LU, Kupper C, Messer M, Petersen $\mathrm{M}$, et al. Mechanical thrombectomy in patients with milder strokes and large vessel occlusions. Stroke. 2018;49(10):2391-7. https:// doi.org/10.1161/STROKEAHA.118.021106.

98. Volny O, Zerna C, Tomek A, Bar M, Rocek M, Padr R, et al. Thrombectomy vs medical management in low NIHSS acute anterior circulation stroke. Neurology. 2020:10.1212/ WNL.0000000000010955. https://doi.org/10.1212/WNL. 0000000000010955 .

99. Marder VJ, Chute DJ, Starkman S, Abolian AM, Kidwell C, Liebeskind D, et al. Analysis of thrombi retrieved from cerebral arteries of patients with acute ischemic stroke. Stroke. 2006;37(8): 2086-93. https://doi.org/10.1161/01.STR.0000230307.03438.94.

100. Brinjikji W, Duffy S, Burrows A, Hacke W, Liebeskind D, Majoie $\mathrm{C}$, et al. Correlation of imaging and histopathology of thrombi in acute ischemic stroke with etiology and outcome: a systematic review. J Neurointerv Surg. 2017;9(6):529-34. https://doi.org/ 10.1136/neurintsurg-2016-012391.

101. Gunning GM, McArdle K, Mirza M, Duffy S, Gilvarry M, Brouwer PA. Clot friction variation with fibrin content; implications for resistance to thrombectomy. J Neurointerv Surg. 2018;10(1):34-8. https://doi.org/10.1136/neurintsurg-2016012721.

102. Duffy S, Farrell M, McArdle K, Thornton J, Vale D, Rainsford E, et al. Novel methodology to replicate clot analogs with diverse composition in acute ischemic stroke. J Neurointerv Surg. 2017;9(5):486-91. https://doi.org/10.1136/neurintsurg-2016012308 .

103. Boeckh-Behrens T, Schubert M, Forschler A, Prothmann S, Kreiser K, Zimmer C, et al. The impact of histological clot composition in embolic stroke. Clin Neuroradiol. 2016;26(2):189-97. https://doi.org/10.1007/s00062-014-0347-x.

104. Yuki I, Kan I, Vinters HV, Kim RH, Golshan A, Vinuela FA, et al. The impact of thromboemboli histology on the performance of a mechanical thrombectomy device. AJNR Am J Neuroradiol. 2012;33(4):643-8. https://doi.org/10.3174/ajnr.A2842.

105. Almekhlafi MA, Hu WY, Hill MD, Auer RN. Calcification and endothelialization of thrombi in acute stroke. Ann Neurol. 2008;64(3):344-8. https://doi.org/10.1002/ana.21404.
106. Dobrocky T, Piechowiak E, Cianfoni A, Zibold F, Roccatagliata L, Mosimann P, et al. Thrombectomy of calcified emboli in stroke. Does histology of thrombi influence the effectiveness of thrombectomy? J Neurointerv Surg. 2018;10(4):345-50. https:// doi.org/10.1136/neurintsurg-2017-013226.

107. De Meyer SF, Stoll G, Wagner DD, Kleinschnitz C. von Willebrand factor: an emerging target in stroke therapy. Stroke. 2012;43(2):599-606. https://doi.org/10.1161/STROKEAHA. 111.628867

108. Lo EH, Ning M. Mechanisms and challenges in translational stroke research. J Investig Med. 2016;64(4):827-9. https://doi. org/10.1136/jim-2016-000104.

109. van Leyen K, Wang X, Selim M, Lo EH. Opening the time window. J Cereb Blood Flow Metab. 2019;39(12):2539-40. https:// doi.org/10.1177/0271678X19882782.

110. Chang Y, Kim BM, Bang OY, Baek JH, Heo JH, Nam HS, et al. Rescue stenting for failed mechanical thrombectomy in acute ischemic stroke: a multicenter experience. Stroke. 2018;49(4):95864. https://doi.org/10.1161/STROKEAHA.117.020072.

111. Baek JH, Kim BM, Heo JH, Kim DJ, Nam HS, Kim YD. Outcomes of endovascular treatment for acute intracranial atherosclerosis-related large vessel occlusion. Stroke. 2018;49(11):2699-705. https://doi.org/10.1161/STROKEAHA. 118.022327.

112. O'Collins VE, Macleod MR, Donnan GA, Horky LL, van der Worp BH, Howells DW. 1,026 experimental treatments in acute stroke. Ann Neurol. 2006;59(3):467-77. https://doi.org/10.1002/ ana.20741.

113. Chamorro A, Amaro S, Castellanos M, Gomis M, Urra X, Blasco $\mathrm{J}$, et al. Uric acid therapy improves the outcomes of stroke patients treated with intravenous tissue plasminogen activator and mechanical thrombectomy. Int J Stroke. 2017;12(4):377-82. https://doi. org/10.1177/1747493016684354.

114. Lyden P, Pryor KE, Coffey CS, Cudkowicz M, Conwit R, Jadhav A, et al. Final results of the RHAPSODY trial: a multi-center, phase 2 trial using a continual reassessment method to determine the safety and tolerability of $3 \mathrm{~K} 3 \mathrm{~A}-\mathrm{APC}$, a recombinant variant of human activated protein $\mathrm{C}$, in combination with tissue plasminogen activator, mechanical thrombectomy or both in moderate to severe acute ischemic stroke. Ann Neurol. 2019;85(1):125-36. https://doi.org/10.1002/ana.25383.

115. Hill MD, Goyal M, Menon BK, Nogueira RG, McTaggart RA, Demchuk AM, et al. Efficacy and safety of nerinetide for the treatment of acute ischaemic stroke (ESCAPE-NA1): a multicentre, double-blind, randomised controlled trial. Lancet. 2020;395(10227):878-87. https://doi.org/10.1016/S01406736(20)30258-0.

Publisher's Note Springer Nature remains neutral with regard to jurisdictional claims in published maps and institutional affiliations. 